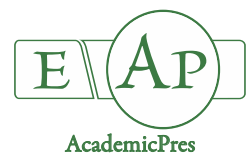

\title{
Drought Avoidance and Phenotypic Flexibility of Sweet Potato (Ipomoea batatas (L.) Lam.) Under Water Scarcity Conditions
}

\author{
Carla S. S. GOUVEIA ${ }^{1 *}$, José F. T. GANANÇA ${ }^{1}$, \\ Humberto G. M. de NÓBREGA ${ }^{1}$, José G. R. de FREITAS ${ }^{1}$, Vincent LEBOT², \\ Miguel Â. A. Pinheiro de CARVALHO ${ }^{1}$
}

\begin{abstract}
${ }^{1}$ ISOPlexis Genebank, University of Madeira, Campus da Penteada, 9020-105, Funchal, Madeira, Portugal; csgouveia@staff.uma.pt (*correspondingauthor); jofitei@staff.uma.pt; humberto.nobrega@staff.uma.pt;jgrfreitas@staff.uma.pt; miguel.carvalho@staff.uma.pt

${ }^{2}$ CIRAD-BIOS, PO Box 946, Port Vila,Vanuatu; lebot@vanuatu.com.vu
\end{abstract}

\begin{abstract}
Sweet potato (Ipomoea batatas (L.) Lam.) is an important staple food in several regions of the world. Water scarcity is the most devastating abiotic stress, with a great impact on crop productivity, food security, and subsistence. Drought restricts the nutrient intake and transport into the plant. Tolerant crops have morphological mechanisms of drought avoidance and/or phenotypic flexibility, showing also good water and nutrient efficiency. However, that information is scarce for sweet potato, which is usually based on physiological traits of plant productivity. Here, we show the physiological responses of eight sweet potato accessions subjected to a 3 months' drought period, by recording their differences for nutrient and leaf chlorophyll content, biomass and stress level. Our results showed that the differences in water use efficiency (WUE, $+68.1 \%$ ), chlorophyll content index (CCI, $-5.3 \%)$, total plant biomass (TPB, $-55.4 \%$ ), nutrient efficiency (NER, $+38.1 \%$ ) and nutrient harvest index $(\mathrm{NHI},+2.9 \%)$ where significantly correlated with the water regime. The water shortage led to a drought avoidance response, with TPB loss in all accessions. Distinct phenotypic flexibility responses were also recorded and explained by the root:shoot ratio (R:S) and stress index (SI) variation of the storage root and shoot growth. This information could be relevant for the development of sweet potato breeding programs, adapting this crop to climate change.
\end{abstract}

Keywords: biomass; chlorophyll content index; drought; nitrogen; nutrient efficiency; root:shoot ratio; stress index Abbreviations: Acc. Accession; CAN Canary Islands; CCI chlorophyll content index; DW dry weight basis; E nitrogen efficiency of utilization; GUI Guinea-Bissau; M total mineral content; MAD Madeira Island; N nitrogen content; NER nitrogen efficiency ratio; NHI nitrogen harvest index; R:S root-to-shoot ratio; SI whole-plant stress index; TPB total plant biomass; WUE water use efficiency

\section{Introduction}

Roots and tubers are the second-most cultivated group of species after cereals, contributing significantly to food and nutritional security. Sweet potato (Ipomoea batatas (L.) Lam.) is a tropical crop tuber, and a worldwide important staple food (Sharma and Kaushal 2016). Asia had the highest sweet potato production in 2017, with $79.6 \mathrm{Mt}$, representing $71 \%$ of worldwide production (FAOSTAT database, www.fao.org, 2019).

Water scarcity is one of the main collateral abiotic consequences of climate change, which is increasingly affecting worldwide crop production. This lack of water decreases productivity, jeopardizing subsistence and food security (Lebot, 2009; Ganança et al., 2015; Ganança et al., 2018). Cultivars are considered to be under drought stress when they face water limitation in the soil, and when they are subjected to the constant loss of water through evapotranspiration triggered by atmospheric conditions (Motsa et al., 2015a).

Sweet potato can be moderately tolerant to drought conditions due to low plant growth habit and extensive root system, and its production is usually done under relatively low input conditions (Smittle et al., 1990; Ekanayake and Collins 2004; Motsa et al., 2015b). The most tolerant plants show inherent morphological mechanisms of drought avoidance and/or phenotypic flexibility, as a natural defense towards water scarceness conditions (Farooq et al., 2009). 
1038

The main drought avoidance response aims to reduce the plant water loss through transpiration, keeping the water uptake through the root system and improving the root biomass yield under drought (Farooq et al., 2009). Water use efficiency (WUE) is a fundamental trait for the distinction of plant drought tolerance. The more tolerant accessions usually display higher WUE by minimizing water loss, through the reduction of stomatal aperture, improving water use for vital activities and plant production (Ganança et al., 2018; Gouveia et al., 2019). In sweet potato, the water deficit reduces root yield and nitrogenous compounds (Ekanayake and Collins, 2004; Sharma and Kaushal, 2016).

Drought reduces the diffusion of nutrients (minerals) from the soil matrix to the roots, and with reduced transpiration rates, the nutrient transport from the roots to the shoots is compromised (Duman, 2012). The nitrogen use efficiency (NUE) can discriminate the accessions according to their aptitude for nutrient absorption and use for yield increase (Mathur and Goel, 2017). Tolerant varieties can display higher yield and NUE in a drought environment or under low input condition (Yuan and Peng, 2017). NUE can be calculated according to the crop and its harvest product, based on the nutrient uptake efficiency (NUpE), harvest index (NHI), incorporation efficiency (efficiency ratio, NER) and utilization efficiency (E) (Siddiqi and Glass 1981; Good et al., 2004; Lammerts van Bueren and Struik, 2017; Mathur and Goel, 2017). The NER is generally utilized to differentiate accessions into efficient and inefficient nutrient use (Good et al., 2004; Mathur and Goel, 2017). Although, very few NUE studies were made on tuber crops (such as cassava, sweet potato, and taro) being mostly done in grain crops (Hartemink et al., 2000; John et al., 2016; Lammerts van Bueren and Struik, 2017).

The phenotypic flexibility comprises the plant growth behavior during scarcity conditions. The underground (roots) and aboveground (leaves) tissues are the main affected organs, but both can have different mechanisms of adaptation to drought. Plants can improve root performance and growth through drought, allowing them to preserve the leaf area and root development under extensive stress (Farooq et al., 2009). According to Rundel and Sharifi (1993), the variation of root:shoot ratio (R:S) during the plants' life cycle allows them to keep the WUE according to the water availability. The water-limited plants can increase the R:S, because of the decline of their leaf growth under water scarcity (Hubick and Gibson, 1993; Laureti et al., 1993). When the plant shoots development stops and root growth continues under drought stress, which can be associated with a general adaptation syndrome (GAS) to water scarcity evolving osmoregulation control (Leshem and Kuiper, 1996). Root crop accessions can show an R:S increase throughout their aging, due to carbon accumulation in the underground tissues (Atwell et al., 1999). The increment of plant photosynthesis during abiotic stress is another good indicator of their capacity to defy drought, where best plant's resistance appears related with higher plant chlorophyll index, and consequently a greater production and plant vigor (Tiwari and Mamrutha, 2013; Mabhaudhi and Modi, 2015; Pereira et al., 2015; Salehi-Lisar and Bakhshayeshan-Agdam, 2016; Gouveia et al., 2018).

The goals of the present study were i) to assess the chlorophyll rate, nutrient, carbon, and water allocation, as well as stress levels of sweet potato accessions submitted to drought, and ii) to correlate these parameters with mechanisms of drought avoidance and phenotypic flexibility.

\section{Materials and Methods}

\section{Experimental sites and drought management}

The sweet potato assay was performed in randomly split-plot field design, established at the ISOPlexis experimental field $\left(32^{\circ} 39^{\prime} \mathrm{N}, 16^{\circ} 55^{\prime} \mathrm{W}, 174 \mathrm{~m}\right.$ a.s.l., Funchal, Madeira, Portugal), during a 5 months' cycle. Eight accessions of sweet potato from Madeira and Canary Islands, and Guinea-Bissau (Table 1) were grown in two independent blocks, one under regular open field conditions (control) and the other under a rain shelter (water deficit). Each accession was then planted in 3 plots (replicates), in eight independent rows, 30 plants per accession in total, with $70 \times 80 \mathrm{~cm}$ in and between the rows, respectively. Three vines were added per plot as blind samples, in both open and shelter environments, with full irrigation.

After stress imposition, two distinct water regimes were applied through a drip irrigation system, $1.6 \mathrm{~mm}$ three times a week for control (based on normal irrigation in Madeiran agricultural practices) and $0.9 \mathrm{~mm}$ three times a week for water deficit ( $43.7 \%$ of water applied to control), per plot, for 3 months. During this period, control plots received about $77 \mathrm{~mm}$ and stressed plots received $54 \mathrm{~mm}$ of water. Control obtained $117.5 \mathrm{~mm}$ from rainfall, during this period. During rain periods, the irrigation of control plots was suspended. Both control and drought plots were assessed periodically for the: photosynthetic active radiation (PAR, 400-700 nm) with a ceptometer (AccuPAR LP-80, USA); volume water content of soil (VWCs) with a soil moisture sensor (WaterScout SM100, USA); air temperature $(\mathrm{Ta})$ and relative air humidity $(\mathrm{RHa})$ with a data logger (Testo $174 \mathrm{H}$, Germany). During the assay, we registered a $24.6 \%$ PAR decrease under the rain shelter when compared to control, on average with $1,514.5 \mu \mathrm{mol}$ $\mathrm{m}^{-2} \mathrm{~s}^{-1}$ for control and 1,142.0 $\mu \mathrm{mol} \mathrm{m} \mathrm{m}^{-2} \mathrm{~s}^{-1}$ for drought. At $10 \mathrm{~cm}$ of depth of homogenized field soil, we registered an average of $12.8 \%$ VWCs for control, representing $35 \%$ of field capacity; and 3.5\% VWCs for drought, representing $10 \%$ of field capacity. On average, control showed $19.46^{\circ} \mathrm{C}$ for $\mathrm{Ta}$ and $68.07 \%$ for RHa; drought showed $22.25^{\circ} \mathrm{C}$ for Ta and $66.40 \%$ for RHa.

All experiments were implemented in a soil-free of chemical contaminants, without adding any fertilizers or phytopharmaceutical products. Weeds were manually removed at regular intervals, to prevent interference in the crop yield.

\section{Harvest and sample preparation}

Three hundred eighty-four sweet potato storage roots and shoots (considering stem, stalk, and leaves) samples of control and drought replicates were harvested, at the end of the agronomic trial. 
Table 1. Accession code, local name, and origin of the eight sweet potatoes (Ipomoea batatas L.) used in this study

\begin{tabular}{ccc}
\hline Acc. ID $^{a}$ & Accession local name & Origin \\
\hline 1036 & Brasileira & Madeira Island \\
1038 & 5 Bicos & Madeira Island \\
2927 & de Flor & Madeira Island \\
3126 & Inglesa & Cadeira Island \\
2937 & Roja & Canary Islands - Tenerife \\
2938 & Cubana & Guinea-Bissau - Bafatá \\
3124 & Vermelha & Guinea-Bissau - Bafatá \\
3125 & Branca & \\
\hline
\end{tabular}

${ }^{\mathrm{a}}$ Accession identification number code used by the ISOPlexis Genebank

All samples were cleaned with running water, weighed with a scale (Sartorius Basic BA2100S, Germany), sliced 2-3 $\mathrm{mm}$ thickness with a mandolin slicer, oven-dried at $65^{\circ} \mathrm{C}$ during $48 \mathrm{~h}$ (Memmert UF260, Germany), and finely milled (IKA-Werke M20, USA). The flour was placed into bags (Termofilm PA/PE), vacuum-sealed (Audionvac VMS153, Netherlands) and stored at $-35^{\circ} \mathrm{C}$ (Liebherr ProfiLine GGPV6570, Germany) until analysis.

\section{Soil chemical and physical properties}

Air-dried soil samples were grinded, sieved $(2 \mathrm{~mm})$ and analyzed by the Agricultural Quality Laboratory at the Directory of Laboratory Services and Agrifood, in Camacha, Madeira, Portugal. Soil chemical and physical properties were analyzed as following: $\mathrm{pH} \mathrm{H}_{2} \mathrm{O}(1: 2.5 \mathrm{w} / \mathrm{v})$; $\mathrm{pH} \mathrm{KCl}(1: 2 \mathrm{w} / \mathrm{v}) ;$ organic matter by Walkley and Black method; nitrate and ammonia content by continuous-flow auto analyzer $(3: 15 \mathrm{w} / \mathrm{v})$; soil texture and particle-size were classified according to the World Reference Database for Soil Resources (IUSS, 2015).

\section{Chlorophyll content index (CCI)}

The CCI in sweet potato fresh leaves was determined, through the technique of chlorophyll fluorescence measurement, using a chlorophyll content meter (OptiSciences CCM-200 PLUS, USA). Three readings were made uniformly along the adaxial leaf surface (left, center and right), avoiding the branching veins. A mean CCI value per main plant leaf was determined in each growth row.

\section{Nitrogen content $(N)$}

Nitrogen concentration in sample flours was determined by the Kjeldahl method AOAC 945-18-B (AOAC 2005), using a distillation and titration automatic unit (Velp Scientifica UDK 152, Italy). Analyses were performed in triplicate, and the average values expressed in $\mathrm{g} / 100 \mathrm{~g}$ of dry flour.

\section{Nefficiency ratio (NER)}

The nutrient efficiency ratio was calculated as the ratio between the plant dry biomass (W) and nitrogen plant uptake $(\mathrm{N})$, according to Steenbjerg and Jakobsen (1963):

$\mathrm{NER}=\mathrm{W} / \mathrm{N}$

The calculations were done in triplicate, and the values expressed in $\mathrm{kg} \mathrm{kg}^{-1}$ of dry flour.

\section{Nefficiency of utilization (E)}

The $\mathrm{E}$ was calculated according to the modified approach by Siddiqi and Glass (1981) as whole-plant nutrient use efficiency (NER), allowing to compare the increase of the produced biomass with NER. They take into account the absolute amount of biomass production increases (W) and NER, given as the ratio of biomass (W) per plant nitrogen $(\mathrm{N})$ uptake capacity (plant $\mathrm{N}$ accumulated):

$$
\mathrm{E}=\mathrm{W} \times \mathrm{NER}=\mathrm{W} \times(\mathrm{W} / \mathrm{N})
$$

The calculations were performed in triplicate, and the values expressed in $\mathrm{kg}$ of dry flour.

Nharvest index (NHI)

The NHI describes the share of nitrogen accumulated in storage roots, concerning the total plant nitrogen uptake (Kolodziejczyk, 2014). It was calculated as the ratio of $\mathrm{N}$ in storage root $(\mathrm{Nt})$ to $\mathrm{N}$ uptake by the plant $(\mathrm{N})$ :

$\mathrm{NHI}=\mathrm{Nt} / \mathrm{N}$

The calculations were performed in triplicate, and the values expressed in \% of dry flour.

\section{Root-to-shoot ratio (R:S)}

The ratio between the storage roots dry weight and respective shoots was calculated for both control and drought conditions (Laureti et al., 1993).

\section{Total mineral content $(M)$}

Total mineral content or ashes was determined gravimetrically by sample flour calcination method AOAC 923.03 (AOAC, 2005), using a furnace (Vulcan Model 3550 , NEY, USA) at $550 \pm 10^{\circ} \mathrm{C}$, for $5 \mathrm{~h}$. The analyses were performed in triplicate, and the values expressed in $\mathrm{g}^{100 \mathrm{~g}^{-1}}$ dry flour.

\section{Total plant biomass (TPB)}

TPB represented the whole-plant biomass calculated from the storage roots and shoots weight of four plants per replicate, dehydrated in an air oven according to Undersander et al. (1993). Each treatment was run in triplicate and results expressed in $g$ of dry flour.

\section{Water use efficiency (WUE)}

WUE was the ratio between total plant dry weight and total water used per plant, and expressed in $\mathrm{g} \mathrm{L}^{-1}$ (Ganança $e t$ al., 2018).

\section{Whole-plant stress index (SI)}

The whole-plant stress index (SI) for each accession was calculated to measure the dimension of the natural response to drought among accessions, using the average dry weight 
1040

(W) of the whole-plant according to the Robinson et al. (2000) equation:

$\mathrm{SI}=\left(\mathrm{W}_{\text {unstressed }}-\mathrm{W}_{\text {stressed }}\right) / \mathrm{W}_{\text {unstressed }}$

The SI ranges from 0 to 1 , in terms of the effect of the environment on plant growth. Plant SI values tend toward 0 when less stressed $(\mathrm{SI} \rightarrow 0)$, and tend to 1 with increasing stress conditions $(\mathrm{SI} \rightarrow 1)$.

\section{Data analysis}

The results are represented as the main average of storage roots and shoots of 3 control $v s 3$ drought replicates, expressed in a dry weight basis. All samples were statistically evaluated with SPSS version 23.0 for Mac, for Pearson correlations, one-way ANOVA and Tukey HSD. The statistically significant differences were expressed with a $p$ value lower than 0.05 .

\section{Results}

WUE, biomass, chlorophyll and nutrient use interactions during drought

All sweet potato accessions decreased their biomass, showing a drought avoidance behaviour during stress. However, they showed a variation in their physiological responses, according to water allocation, chlorophyll rate and nutrient use at the whole-plant level (Table 2).
On average, total plant biomass (TPB) of sweet potato decreased from 533.1 to $237.6 \mathrm{~g}$ (-55.4\%). Acc. 3124 and 3125 showed limited weight loss variation, while acc. 2937 and 2938 had the lowest biomass content in all drought assays.

Relatively to water use efficiency (WUE), the sweet potato acc. increased the WUE from 4.7 to $7.9 \mathrm{~g} \mathrm{~L}^{-1}$ $(+68.1 \%)$ on average, with the acc. 3124 and 3125 showing the highest significant WUE values. The acc. 3126 and 2938 were the exception, by decreasing WUE, with both of them having the highest water loss through transpiration.

Slight variations of chlorophyll activity, i.e. chlorophyll content index (CCI), were registered in drought-stressed sweet potato accessions. Their CCI decreased from 30.4 to $28.8(-5.3 \%)$, by lowering the photosynthetic rate, except for acc. 1036 and 3126.

$\mathrm{N}$ efficiency ratio (NER) for all the sweet potato acc. increased, from 11.3 to $15.6 \mathrm{~kg} \mathrm{~kg}^{-1}$ (+38.1\%), with acc. 2937 and 2938 showing the highest significant NER. N efficiency of utilization (E) increased from 4.6 to $7.1 \mathrm{~kg}$ (+54.4\%), where acc. 2937 and 2938 shows a significant $\mathrm{E}$ increase. Meanwhile, E content of acc. 1036 decreased.

$\mathrm{N}$ harvest index (NHI), on average, increased from 27.9 to $30.8 \%$ (+2.9\%), with acc. 2927 and 2937 showing significantly higher NHI content, and 1038 acc. being the only one where an NHI decrease was observed.

Table 2. Chlorophyll content index (CCI), total plant biomass (TPB), water use efficiency (WUE), N efficiency ratio (NER), N efficiency utilization (E) and $\mathrm{N}$ harvest index $(\mathrm{NHI})$ of sweet potato (I. batatas) whole-plant accession

\begin{tabular}{|c|c|c|c|c|c|c|c|c|}
\hline \multicolumn{3}{|c|}{ Ipomoea batatas $\mathrm{L}$. } & $\mathrm{CCI}^{\dagger+}$ & $\begin{array}{c}\mathrm{TPB}^{+\dagger} \\
(\mathrm{g})\end{array}$ & $\begin{array}{c}\mathrm{WUE}^{+\dagger} \\
\left(\mathrm{gL}^{-1}\right)\end{array}$ & $\begin{array}{c}\mathrm{NER}^{\dagger+} \\
\left(\mathrm{kg} \mathrm{kg}^{-1}\right)\end{array}$ & $\begin{array}{l}\mathrm{E}^{+\dagger} \\
(\mathrm{kg})\end{array}$ & $\begin{array}{c}\mathrm{NHI}^{+\dagger} \\
(\%)\end{array}$ \\
\hline \multirow{8}{*}{ MAD } & \multirow{2}{*}{1036} & Control & $18.5 \pm 2.4^{\mathrm{ab}}$ & $377.5 \pm 62.9^{\text {abcd }}$ & $3.6 \pm 0.9^{\mathrm{abc}}$ & $11.6 \pm 2.3^{\mathrm{abcd}}$ & $4.5 \pm 1.4^{\mathrm{abcd}}$ & $30.0 \pm 1.8^{\text {bcdef }}$ \\
\hline & & Drought & $31.3 \pm 7.2^{\text {abcde }}$ & $231.2 \pm 70.4^{\mathrm{abc}}$ & $6.2 \pm 1.3^{\mathrm{abcd}}$ & $9.8 \pm 0.0^{\mathrm{ab}}$ & $3.9 \pm 0.0^{\mathrm{abc}}$ & $36.1 \pm 0.0^{\mathrm{efg}}$ \\
\hline & \multirow{2}{*}{1038} & Control & $37.9 \pm 5.3^{\mathrm{de}}$ & $1038.6 \pm 176.6^{e}$ & $9.3 \pm 2.2^{\text {cde }}$ & $9.8 \pm 0.3^{\mathrm{ab}}$ & $3.7 \pm 0.2^{\mathrm{ab}}$ & $28.1 \pm 1.9^{\text {bcde }}$ \\
\hline & & Drought & $28.6 \pm 3.5^{\text {abcde }}$ & $342.4 \pm 106.8^{\mathrm{abcd}}$ & $11.1 \pm 3.4^{\mathrm{def}}$ & $15.3 \pm 2.4^{d}$ & $6.4 \pm 1.4^{\text {cde }}$ & $25.0 \pm 0.6^{\mathrm{abc}}$ \\
\hline & \multirow{2}{*}{2927} & Control & $41.6 \pm 4.8^{\mathrm{e}}$ & $512.8 \pm 229.0^{\mathrm{cd}}$ & $4.8 \pm 1.8^{\mathrm{abc}}$ & $10.8 \pm 2.1^{\mathrm{abc}}$ & $4.0 \pm 1.0^{a b c}$ & $28.5 \pm 1.5^{\text {bcdef }}$ \\
\hline & & Drought & $35.9 \pm 0.7^{\mathrm{de}}$ & $268.4 \pm 125.8^{\mathrm{abc}}$ & $7.8 \pm 3.7^{\mathrm{cd}}$ & $14.5 \pm 1.2^{\mathrm{cd}}$ & $5.9 \pm 0.6^{\text {bcde }}$ & $40.5 \pm 1.0^{\mathrm{g}}$ \\
\hline & \multirow{2}{*}{3126} & Control & $25.8 \pm 1.5^{\mathrm{abcd}}$ & $731.4 \pm 367.6^{\mathrm{de}}$ & $6.9 \pm 3.0^{\mathrm{bcd}}$ & $9.3 \pm 0.7^{\mathrm{a}}$ & $3.9 \pm 0.4^{\mathrm{abc}}$ & $26.5 \pm 3.0^{\mathrm{abcd}}$ \\
\hline & & Drought & $31.5 \pm 5.6^{\text {abcde }}$ & $135.8 \pm 25.1^{\mathrm{abc}}$ & $4.6 \pm 0.8^{\mathrm{abc}}$ & $13.8 \pm 0.7^{\mathrm{bcd}}$ & $7.0 \pm 0.6^{\mathrm{de}}$ & $27.1 \pm 3.1 \mathrm{abcd}$ \\
\hline \multirow{4}{*}{ CAN } & \multirow{2}{*}{2937} & Control & $21.0 \pm 2.5^{a b c}$ & $106.4 \pm 36.8^{a b c}$ & $0.8 \pm 0.3^{a}$ & $15.2 \pm 2.4^{d}$ & $7.2 \pm 1.8^{\mathrm{e}}$ & $34.7 \pm 4.2^{\text {defg }}$ \\
\hline & & Drought & $18.3 \pm 2.4^{a}$ & $22.9 \pm 21.0^{a}$ & $1.1 \pm 0.4^{\mathrm{a}}$ & $24.6 \pm 0.0^{\mathrm{e}}$ & $12.9 \pm 0.0^{\mathrm{g}}$ & $36.7 \pm 0.0^{\mathrm{fg}}$ \\
\hline & \multirow{2}{*}{2938} & Control & $32.3 \pm 3.7^{\text {bcde }}$ & $523.5 \pm 116.5^{\mathrm{cd}}$ & $1.7 \pm 0.8^{\mathrm{ab}}$ & $12.5 \pm 1.8^{\mathrm{abcd}}$ & $5.3 \pm 0.9^{\text {abcde }}$ & $26.0 \pm 0.3^{\mathrm{abc}}$ \\
\hline & & Drought & $25.6 \pm 0.8^{\mathrm{abcd}}$ & $58.1 \pm 28.4^{\mathrm{ab}}$ & $1.6 \pm 1.2^{\mathrm{ab}}$ & $20.8 \pm 1.5^{\mathrm{e}}$ & $9.9 \pm 0.7^{f}$ & $26.4 \pm 8.7^{\mathrm{abcd}}$ \\
\hline \multirow{4}{*}{ GUI } & \multirow{2}{*}{3124} & Control & $31.2 \pm 6.7^{\text {abcde }}$ & $507.2 \pm 108.1^{\mathrm{cd}}$ & $5.0 \pm 1.5^{a b c}$ & $9.2 \pm 1.0^{\mathrm{a}}$ & $3.1 \pm 0.5^{a}$ & $19.0 \pm 5.0^{\mathrm{a}}$ \\
\hline & & Drought & $26.8 \pm 3.0^{\mathrm{abcd}}$ & $449.9 \pm 23.6^{\mathrm{bcd}}$ & $16.5 \pm 2.2^{f}$ & $10.8 \pm 1.1^{\mathrm{abc}}$ & $3.8 \pm 0.4^{\mathrm{ab}}$ & $22.4 \pm 2.3^{\mathrm{ab}}$ \\
\hline & \multirow{2}{*}{3125} & Control & $35.1 \pm 8.2^{\mathrm{de}}$ & $467.8 \pm 173.3^{\mathrm{bcd}}$ & $5.1 \pm 1.2^{\mathrm{abc}}$ & $12.0 \pm 1.9^{\mathrm{abcd}}$ & $5.2 \pm 1.1^{\text {abcde }}$ & $30.8 \pm 1.4^{\text {bcdef }}$ \\
\hline & & Drought & $32.5 \pm 5.7^{\text {cde }}$ & $391.8 \pm 45.4^{\mathrm{abcd}}$ & $14.2 \pm 1.3^{\text {ef }}$ & $15.2 \pm 1.1^{\mathrm{d}}$ & $7.1 \pm 0.3^{\mathrm{e}}$ & $32.4 \pm 3.3^{\text {cdefg }}$ \\
\hline & \multirow{2}{*}{ Mean } & Control & 30.4 & 533.1 & 4.7 & 11.3 & 4.6 & 27.9 \\
\hline & & Drought & 28.8 & 237.6 & 7.9 & 15.6 & 7.1 & 30.8 \\
\hline & \multirow{2}{*}{ Min } & Control & 18.5 & 106.4 & 0.8 & 9.2 & 3.1 & 19.0 \\
\hline & & Drought & 18.3 & 22.9 & 1.1 & 9.8 & 3.8 & 22.4 \\
\hline & \multirow{2}{*}{ Max } & Control & 41.6 & 1038.5 & 9.3 & 15.2 & 7.2 & 34.7 \\
\hline & & Drought & 35.9 & 449.9 & 16.5 & 24.6 & 12.9 & 40.5 \\
\hline
\end{tabular}

Data are expressed in dry weight basis (DW) and represent the mean \pm SD of three independent replications per accession. Means not sharing the same letters between columns are significantly different (Tukey HSD, $p \leq 0.05$ ).

${ }^{+}$Significant differences between control and drought stress conditions (One-way ANOVA, $" p \leq 0.01$ )

Control is well-watered, drought is water scarcity. 


\section{Nutrient efficiency ability during drought}

The sweet potato acc. varied their nutrient allocation, between underground storage roots and aboveground shoots, along with the mineral (M), nitrogen $(\mathrm{N})$, NER and $\mathrm{E}$ traits (Table 3). The soil of the experimental plot, at $0.2 \mathrm{~m}$ sampling depth, showed moderate inorganic mineral content $\left(\mathrm{NO}_{3}^{-}\right.$and $\left.\mathrm{NH}_{4}^{+}\right)$, with a slightly acidic $\mathrm{pH}$ 6.6, and silt clay texture (data not shown).

In general, the sweet potato acc. showed a lower $M$ content in storage roots relatively to shoots, in both experimental conditions. They had a slight increase of M-

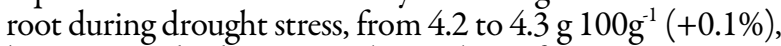
but registered a decrease in the M-shoot, from 12.2 to $10.5 \mathrm{~g}$ $100 \mathrm{~g}^{-1}(-1.7 \%)$. Acc. 3125 had the highest M-root content

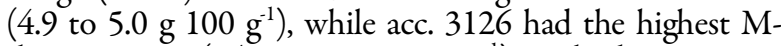

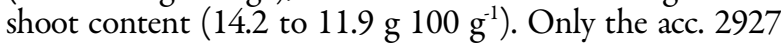
and 2937 showed a decrease in the mineral content in both plant organs.

The sweet potato acc. exhibited a higher $\mathrm{N}$ content in shoots when compared to storage roots, in both experimental conditions. Although, under water scarcity, sweet potato decreased the $\mathrm{N}$ content in both organs. In average, the $\mathrm{N}$-root slightly decreased from 1.0 to $0.9 \mathrm{~g} 100$ $\mathrm{g}^{-1}(-0.1 \%)$, and the $\mathrm{N}$-shoot dropped from 2.6 to $2.1 \mathrm{~g} 100$ $\mathrm{g}^{-1}(-0.5 \%)$. Acc. 3126 showed the highest decrease of $\mathrm{N}$ -

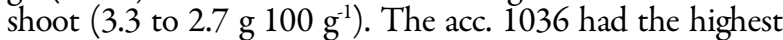
$\mathrm{N}$-root content (1.0 to $1.5 \mathrm{~g} / 100 \mathrm{~g}$ ) and was the exception by showing an $\mathrm{N}$ increase in both organs during drought.

Both NER and $\mathrm{E}$ were higher in the underground organs. Under stress, both NER-root and NER-shoot of the sweet potato acc. increased from 26.8 to $32.6 \mathrm{~kg} \mathrm{~kg}^{-1}$ $(+21.6 \%)$ and from 5.6 to $8.9 \mathrm{~kg} \mathrm{~kg}^{-1}(+58.9 \%)$, respectively. The acc. 2938 showed the highest NER-root content, with $32.4 \mathrm{~kg} \mathrm{~kg}^{-1}$ for control and $51.1 \mathrm{~kg} \mathrm{~kg}^{-1}$ for stress conditions. The E-root and E-shoot had an overall increase from 7.1 to
$9.1 \mathrm{~kg}(+28.2 \%)$, and from 0.8 to $1.6 \mathrm{~kg}(+100 \%)$, respectively. The highest E-root content was registered at acc. 2938 ( 9.3 to $14.8 \mathrm{~kg}$ ).

\section{Drought stress index and root-to-shoot relationship}

All accessions showed a decrease of TPB, as an effect of low water availability, exhibiting differences within the plant organs development, which can be described by the phenotypic flexibility through the R:S and SI (Fig. 1).

The R:S shows the plant capacity to maintain an active balance between the underground storage roots and aboveground shoots, under drought. In control conditions, the R:S ranged from 1:0.6 to 1:7 for acc. 1036 and 1038, respectively. The acc. 1038 showed the highest variation between the weight of the organs, where shoots were 7 times lighter than storage roots, in control conditions. Overall, drought decreased the sweet potato R:S due to the investment in shoot development. The acc. 1036 showed the highest investment in shoot production, and the biggest $\mathrm{R}: S$ decrease during drought (1:0.6 to $1: 0.1,-81.9 \%)$. The exception was for sweet potato acc. 2938 (1:1.6 to 1:2, $+43.8 \%)$, that was the only one which showed an R:S increase. This can indicate that it was the only one that decreased shoot development during drought, in favor of tuber growth.

The SI was used to assess the differences in stress strength for each acc., showing the impact of drought conditions on their innate growth $(0<S I<1)$. The acc. 3124 and 3125 registered the lowest SI value, around 0.1 (SI $\rightarrow 0$ ), being the less drought-sensitive, by showing higher growth capacity and a more tolerant response to water scarcity. On the other hand, acc. 3126, 2937 and 2938 showed to be the most stress-sensitive, with SI values around $0.8(\mathrm{SI} \rightarrow 1)$.

Table 3. Mineral (M), nitrogen (N), N efficiency ratio (NER) and N efficiency utilization (E) from the storage roots and shoots of sweet potato (I. batatas) accessions

\begin{tabular}{|c|c|c|c|c|c|c|c|c|c|c|}
\hline \multirow{2}{*}{\multicolumn{3}{|c|}{ Ipomoea batatas $\mathrm{L}$. }} & \multirow{2}{*}{\multicolumn{2}{|c|}{$\begin{array}{c}\mathrm{M} \\
\left(\mathrm{g} 100 \mathrm{~g}^{-1}\right)\end{array}$}} & \multirow{2}{*}{\multicolumn{2}{|c|}{$\begin{array}{c}\mathrm{N} \\
\left(\mathrm{g} 100 \mathrm{~g}^{-1}\right)\end{array}$}} & \multirow{2}{*}{\multicolumn{2}{|c|}{$\begin{array}{c}\text { NER } \\
\left(\mathrm{kg} \mathrm{kg}^{-1}\right)\end{array}$}} & \multicolumn{2}{|c|}{$\begin{array}{c}\mathrm{E} \\
(\mathrm{kg})\end{array}$} \\
\hline & & & & & & & & & & \\
\hline \multirow{9}{*}{ MAD } & \multirow{3}{*}{1036} & & & & & & & & & \\
\hline & & Control & $4.2 \pm 0.2^{\mathrm{abc}}$ & $11.1 \pm 0.6^{\text {bede }}$ & $1.0 \pm 0.1^{\text {abcd }}$ & $2.3 \pm 0.0^{\mathrm{cd}}$ & $23.8 \pm 6.2^{\mathrm{abc}}$ & $6.4 \pm 0.8^{\text {bed }}$ & $5.7 \pm 2.3^{\mathrm{abc}}$ & $1.0 \pm 0.2^{\text {bcd }}$ \\
\hline & & Drought & $4.5 \pm 0.1^{\mathrm{abc}}$ & $11.0 \pm 0.2^{\text {bede }}$ & $1.5 \pm 0.0^{\mathrm{c}}$ & $2.6 \pm 0.1^{\mathrm{cdc}}$ & $14.1 \pm 0.0^{\mathrm{a}}$ & $7.4 \pm 0.0^{\mathrm{cde}}$ & $2.9 \pm 0.0^{\mathrm{a}}$ & $1.4 \pm 0.0^{\mathrm{def}}$ \\
\hline & \multirow{2}{*}{1038} & Control & $4.0 \pm 0.3^{\mathrm{abc}}$ & $13.8 \pm 0.1$ fy & $1.1 \pm 0.1 \mathrm{bcd}$ & $2.8 \pm 0.1 \mathrm{def}$ & $24.1 \pm 2.0 \mathrm{abc}$ & $4.2 \pm 0.1^{\mathrm{ab}}$ & $6.4 \pm 0.6^{\mathrm{abc}}$ & $0.5 \pm 0.0^{\mathrm{ab}}$ \\
\hline & & Drought & $4.1 \pm 0.4^{\mathrm{abc}}$ & $11.8 \pm 0.7^{\text {cdeffg }}$ & $0.7 \pm 0.1^{\mathrm{a}}$ & $2.0 \pm 0.2^{b c}$ & $39.0 \pm 6.2^{\mathrm{bcd}}$ & $7.4 \pm 1.3^{\mathrm{cde}}$ & $10.3 \pm 2.1^{\mathrm{bcde}}$ & $1.1 \pm 0.3^{\mathrm{cd}}$ \\
\hline & \multirow{2}{*}{2927} & Control & $4.6 \pm 0.6^{\mathrm{abc}}$ & $11.6 \pm 1.4^{\mathrm{cdef}}$ & $1.0 \pm 0.1 \mathrm{abcd}$ & $2.5 \pm 0.3^{\text {cde }}$ & $20.8 \pm 3.1 \mathrm{ab}$ & $6.7 \pm 1.6^{\mathrm{cd}}$ & $4.2 \pm 0.9^{\mathrm{ab}}$ & $1.1 \pm 0.4^{\mathrm{cd}}$ \\
\hline & & Drought & $4.5 \pm 0.1^{\mathrm{abc}}$ & $9.9 \pm 0.7 \mathrm{abcd}$ & $1.1 \pm 0.1^{\mathrm{cde}}$ & $1.7 \pm 0.1^{\mathrm{ab}}$ & $20.9 \pm 1.4^{\mathrm{ab}}$ & $10.1 \pm 1.2^{\mathrm{fg}}$ & $4.9 \pm 0.3 \mathrm{abc}$ & $1.7 \pm 0.3^{\mathrm{cfg}}$ \\
\hline & \multirow{2}{*}{3126} & Control & $3.7 \pm 0.3^{a}$ & $14.2 \pm 1.3^{g}$ & $1.2 \pm 0.2 \mathrm{de}$ & $3.3 \pm 0.1^{f}$ & $26.0 \pm 4.8 \mathrm{abc}$ & $3.4 \pm 0.3^{a}$ & $7.9 \pm 1.7^{\text {abcd }}$ & $0.4 \pm 0.1^{\mathrm{a}}$ \\
\hline & & Drought & $4.0 \pm 0.1^{\mathrm{abc}}$ & $11.9 \pm 0.5^{\text {cdefg }}$ & $1.0 \pm 0.1 \mathrm{abcd}$ & $2.7 \pm 0.1^{\mathrm{cde}}$ & $33.3 \pm 1.5^{\text {bcd }}$ & $6.7 \pm 0.3^{\mathrm{cd}}$ & $10.8 \pm 0.2^{\text {cde }}$ & $1.2 \pm 0.1^{\mathrm{cde}}$ \\
\hline \multirow{4}{*}{ CAN } & \multirow{2}{*}{2937} & Control & $4.0 \pm 0.4^{\mathrm{abc}}$ & $9.6 \pm 1.0^{\mathrm{abc}}$ & $1.1 \pm 0.2^{\text {bcd }}$ & $2.0 \pm 0.0^{b c}$ & $29.4 \pm 8.8 \mathrm{abc}$ & $8.0 \pm 0.2^{\text {def }}$ & $9.3 \pm 3.8^{\text {bcdc }}$ & $1.3 \pm 0.1^{\mathrm{cdcf}}$ \\
\hline & & Drought & $3.7 \pm 0.0^{a}$ & $7.6 \pm 0.0^{a}$ & $0.8 \pm 0.0^{\mathrm{abc}}$ & $1.5 \pm 0.2^{a}$ & $41.0 \pm 0.0^{\mathrm{cd}}$ & $15.1 \pm 0.0^{\mathrm{h}}$ & $13.2 \pm 0.0^{\mathrm{dc}}$ & $3.1 \pm 0.0^{\mathrm{h}}$ \\
\hline & \multirow{2}{*}{2938} & Control & $4.4 \pm 0.2^{\mathrm{abc}}$ & $11.7 \pm 0.3^{\text {def }}$ & $0.9 \pm 0.1$ abcd & $2.5 \pm 0.2^{\mathrm{cde}}$ & $32.4 \pm 5.3 \mathrm{abc}$ & $5.5 \pm 0.4 \mathrm{abc}$ & $9.3 \pm 2.2$ bcde & $0.8 \pm 0.0^{\mathrm{abc}}$ \\
\hline & & Drought & $4.4 \pm 0.0^{\mathrm{abc}}$ & $8.9 \pm 1.0^{\mathrm{ab}}$ & $0.6 \pm 0.2^{a}$ & $1.7 \pm 0.1 \mathrm{ab}$ & $51.1 \pm 21.2^{\mathrm{d}}$ & $11.2 \pm 0.9^{g}$ & $14.8 \pm 6.4^{\mathrm{e}}$ & $2.1 \pm 0.2^{g}$ \\
\hline \multirow{4}{*}{ GUI } & \multirow{2}{*}{3124} & Control & $3.9 \pm 0.8^{\mathrm{ab}}$ & $12.9 \pm 1.1^{\text {efg }}$ & $0.7 \pm 0.1^{a}$ & $3.0 \pm 0.3^{\text {ef }}$ & $33.6 \pm 11.7^{\text {bcd }}$ & $3.9 \pm 0.6^{a}$ & $7.7 \pm 3.5$ abcd & $0.5 \pm 0.1^{\mathrm{ab}}$ \\
\hline & & Drought & $4.1 \pm 0.2^{\mathrm{abc}}$ & $12.9 \pm 0.9^{\mathrm{cfg}}$ & $0.7 \pm 0.0^{\mathrm{ab}}$ & $2.6 \pm 0.3^{\text {cde }}$ & $33.9 \pm 1.1^{\text {bed }}$ & $4.2 \pm 0.8 \mathrm{ab}$ & $8.4 \pm 0.5^{\text {abcd }}$ & $0.4 \pm 0.1 \mathrm{ab}$ \\
\hline & \multirow{2}{*}{3125} & Control & $4.9 \pm 0.6^{b c}$ & $12.3 \pm 1.4 \mathrm{deffg}$ & $1.1 \pm 0.1^{\mathrm{cde}}$ & $2.5 \pm 0.2^{\mathrm{cde}}$ & $24.3 \pm 2.4 \mathrm{abc}$ & $6.5 \pm 1.4^{\mathrm{bcd}}$ & $6.5 \pm 0.8 \mathrm{abc}$ & $1.1 \pm 0.3^{\mathrm{cd}}$ \\
\hline & & Drought & $5.0 \pm 0.3^{c}$ & $10.3 \pm 0.5^{\mathrm{bcd}}$ & $1.0 \pm 0.2 \mathrm{abcd}$ & $2.1 \pm 0.1 \mathrm{bc}$ & $27.6 \pm 4.2 \mathrm{abc}$ & $9.4 \pm 0.8$ efg & $7.6 \pm 1.0 \mathrm{abcd}$ & $1.8 \pm 0.2$ f \\
\hline & \multirow{2}{*}{$\begin{array}{c}\text { Mea } \\
\mathrm{n}\end{array}$} & Control & 4.2 & 12.2 & 1.0 & 2.6 & 26.8 & 5.6 & 7.1 & 0.8 \\
\hline & & Drought & 4.3 & 10.5 & 0.9 & 2.1 & 32.6 & 8.9 & 9.1 & 1.6 \\
\hline & \multirow{2}{*}{ Min } & Control & 3.7 & 9.6 & 0.7 & 2.0 & 20.8 & 3.4 & 4.2 & 0.4 \\
\hline & & Drought & 3.7 & 7.6 & 0.6 & 1.5 & 14.1 & 4.2 & 2.9 & 0.4 \\
\hline & \multirow{2}{*}{ Max } & Control & 4.9 & 14.2 & 1.2 & 3.3 & 33.6 & 8.0 & 9.3 & 1.3 \\
\hline & & Drought & 5.0 & 12.9 & 1.5 & 2.7 & 51.1 & 15.1 & 14.8 & 3.1 \\
\hline
\end{tabular}

Data are expressed in dry weight basis (DW) and represent the mean \pm SD of three independent replicates per accession.

Means not sharing the same letters between columns are significantly different (Tukey HSD, $p \leq 0.05$ ).

${ }^{+\dagger}$ Significant differences between control and drought stress conditions (One-way ANOVA, $p \leq 0.01$ )

Control is well-watered, drought is water scarcity. 
1042

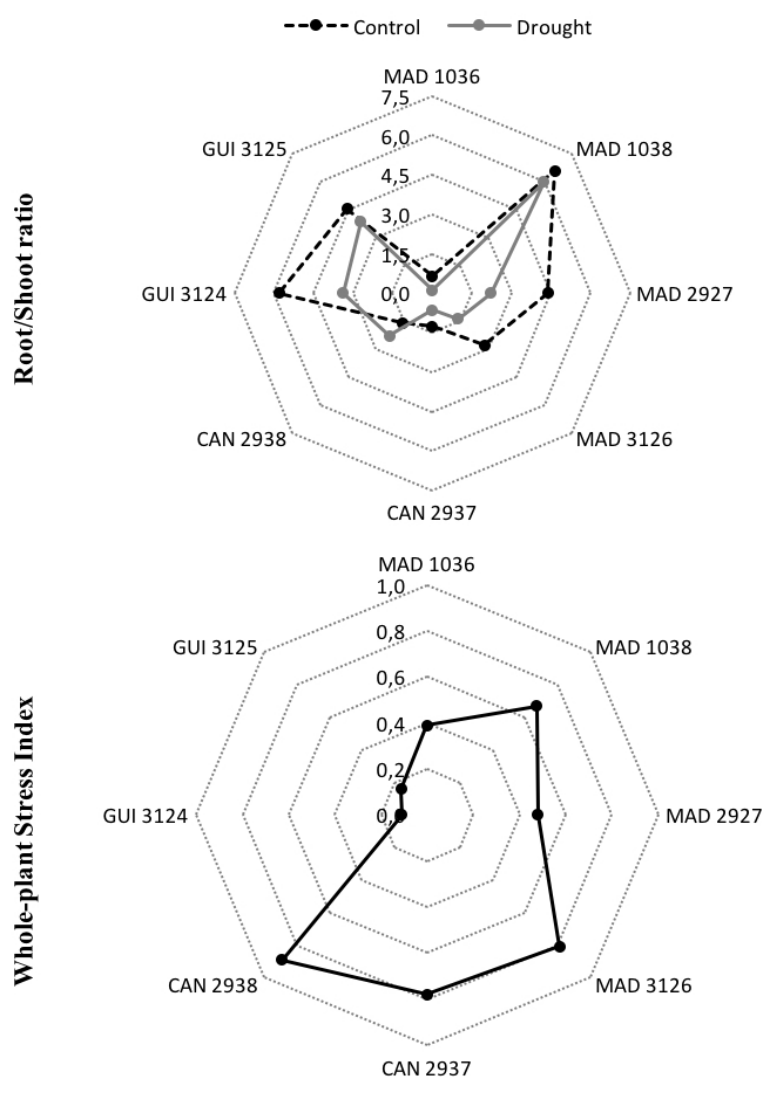

Sweet Potato (Ipomoea batatas L.)

Fig. 1. Stress index (SI) and R:S in sweet potato (I. batatas) accessions, under control and drought conditions. Sweet potato accessions with ISOPlexis Genebank identification number code, from CAN Canary Islands, MAD Madeira Island and GUI Guinea-Bissau. Data are expressed in dry weight basis and represent the mean of three independent replicates per accession. Control is well-watered, drought is water scarcity.

\section{Pearson correlation coefficients between traits}

Seventy-seven significant correlations were found between 16 sweet potato traits, of which 34 were strong, with $r \geq 0.50$ (Table 4). TPB and WUE had a moderate positive correlation, while CCI showed a negative correlation with NER-shoot and a significant positive correlation with M-shoot. R:S had negative correlations with NHI, NER-shoot, and E-shoot. N-root showed positive correlations with $\mathrm{NHI}$ and $\mathrm{M}$-root, and negative correlations with E, NER-root, and E-root. NER also had a positive correlation with $\mathrm{N}$-root. The sweet potato acc. with the highest TPB showed also the highest CCI, WUE, R:S, $\mathrm{M}$-shoot, and $\mathrm{N}$-shoot contents. We also observed that lower NER and NHI corresponded to greater CCI, TPB and WUE values.

\section{Discussion}

Relation between water scarcity and plant bealth development

The water scarcity is one of the most threatening environmental stresses for crop yield, with undesirable impacts in the main staple food crops (Lebot, 2009; Ganança et al., 2015). In this study, all acc. decreased their biomass under water scarcity, a drought avoidance response. They also showed variations in organ growth between treatments, demonstrating phenotypic flexibility. Besides the loss of biomass, changes amongst the CCI and WUE contents were also recorded.

Sweet potato lost on average more than half of the TPB due to drought. Motsa et al. (2015b) and Smittle et al. (1990) reported that sweet potato cultivars had good ability to alter their growth features, mainly the development of an extensive root system. They adapt to low input conditions, earning moderate tolerance to drought stress through greater phenotypic plasticity. Plants can improve their biomass content through the constant adjustment of shoot and root growth rates, according to the resources uptake (Atwell et al., 1999). Overall, the sweet potato acc. showed a dynamic balance between underground and aboveground organs, during drought, leading to an R:S ratio decrease, which implies a generalized trend for developing the shoot rather than the storage roots. One sweet potato accession (2938) was the exception, registering an R:S increase dictated by tubers growth instead of providing energy for the development of the shoots. Probably, this acc. had a bigger tendency for carbon investment in underground structures, as Atwell et al. (1999) proposed to be possible on roots development. Being this the acc with the smallest canopy, it could favor the storage root growth over shoot development, reducing the shoot area as a way to avoid shoot water loss (van den Boogaard et al., 1995; Motsa et al., 2015a). This can be a plant response, related to GAS, with water scarcity involving osmoregulation and WUE increase (Leshem and Kuiper, 1996). In cotton and peanut cultivars, the leaf area reduction occurs when they are submitted to lack of water or nutrients, inducing a higher R:S (Harris 1992; Hubick and Gibson, 1993; Laureti et al., 1993; Atwell et al., 1999). Notwithstanding the biomass loss in all accessions, we also registered low SI in two sweet potato accessions (3124 and 3125). The low SI is related to low $\mathrm{TPB}$ variation between control and drought environments, being the best ones in maintaining their growth under water scarcity.

The CCI can indirectly infer the plant photosynthetic rate, through the association of the photosynthetic electron transport between shoots (Salehi-Lisar and BakhshayeshanAgdam, 2016). It can indicate the plant drought stress tolerance, where the bigger the plant chlorophyll index, the better the plant resistance to water scarcity (Tiwari and Mamrutha, 2013; Salehi-Lisar and Bakhshayeshan-Agdam 2016; Gouveia et al., 2018). Although, drought lowered the sweet potato CCI content (-5.3\%). The lower CCI values indicate a lower photosynthetic activity (Shao et al., 2015). According to Mabhaudhi and Modi (2015) and Osakabe et al. (2014), the photosynthesis down-regulation resulted from the decrease of the intracellular $\mathrm{CO}_{2}$ availability, 
Table 4. Pearson correlation coefficients of the analyzed traits of sweet potato (I. batatas) in control and drought stress conditions

\begin{tabular}{|c|c|c|c|c|c|c|c|c|c|c|c|c|c|c|c|}
\hline Variables & 1 & 2 & 3 & 4 & 5 & 6 & 7 & 8 & 9 & 10 & 11 & 12 & 13 & 14 & 15 \\
\hline 1. CCI & - & & & & & & & & & & & & & & \\
\hline 2. ТPB & $0.43^{* *}$ & - & & & & & & & & & & & & & \\
\hline 3. WUE & 0.24 & $0.44^{* *}$ & - & & & & & & & & & & & & \\
\hline 4. NER & $-0.39^{* *}$ & $-0.65^{* *}$ & -0.33 & - & & & & & & & & & & & \\
\hline 5. E & $-0.40^{* *}$ & $-0.65^{* *}$ & $-0.37^{\prime \prime}$ & $0.99^{* *}$ & - & & & & & & & & & & \\
\hline 6. NHI & -0.09 & $-0.29^{*}$ & -0.16 & $0.31^{*}$ & $0.33^{*}$ & - & & & & & & & & & \\
\hline 7. R:S & $0.43^{* *}$ & $0.50^{* *}$ & $0.38^{\prime \prime}$ & -0.27 & $-0.32^{*}$ & $-0.53^{* *}$ & - & & & & & & & & \\
\hline 8. SI & -0.05 & 0.00 & -0.36 & 0.10 & 0.18 & 0.20 & -0.28 & - & & & & & & & \\
\hline 9. M-root & $0.30^{*}$ & 0.07 & 0.21 & -0.14 & -0.16 & 0.28 & -0.08 & 0.25 & - & & & & & & \\
\hline 10. M-shoot & $0.34^{*}$ & $0.76^{* *}$ & $0.42^{\prime \prime}$ & $-0.85^{* *}$ & $-0.82^{* *}$ & $-0.54^{* *}$ & $0.46^{* *}$ & -0.11 & -0.04 & - & & & & & \\
\hline 11. N-root & 0.16 & 0.22 & 0.01 & $0.45^{* *}$ & $-0.37^{* *}$ & $0.62^{* *}$ & $-0.35^{*}$ & 0.31 & $0.33^{*}$ & 0.19 & - & & & & \\
\hline 12. N-shoot & 0.27 & $0.63^{* *}$ & 0.21 & $-0.86^{* *}$ & $-0.80^{* *}$ & $-0.55^{* *}$ & $0.29^{*}$ & -0.057 & -0.10 & $0.90^{* *}$ & 0.27 & - & & & \\
\hline $\begin{array}{l}\text { 13. NER- } \\
\text { root }\end{array}$ & $-0.31^{*}$ & $-0.38^{* *}$ & -0.18 & $0.65^{* *}$ & $0.63^{* *}$ & $-0.47^{* *}$ & 0.13 & -0.21 & $-0.39^{* *}$ & $-0.33^{*}$ & $-0.84^{* *}$ & $-0.35^{*}$ & - & & \\
\hline $\begin{array}{l}\text { 14. NER- } \\
\text { shoot }\end{array}$ & $-0.29^{*}$ & $-0.68^{* *}$ & -0.32 & $0.91^{* *}$ & $0.89^{* *}$ & $0.60^{* *}$ & $-0.40^{* *}$ & -0.13 & 0.06 & $-0.92^{* *}$ & -0.16 & $-0.91^{* *}$ & $0.33^{*}$ & - & \\
\hline 15. E-root & $-0.37^{*}$ & $-0.42^{* *}$ & -0.27 & $0.73^{* *}$ & $0.74^{* *}$ & $-0.33^{*}$ & 0.01 & 0.13 & $-0.42^{* *}$ & $-0.39^{* *}$ & $-0.72^{* *}$ & $-0.38^{* *}$ & $0.96^{* *}$ & $0.40^{* *}$ & - \\
\hline 16. E-shoot & -0.28 & $-0.68^{* *}$ & -0.32 & $0.88^{* *}$ & $0.88^{* *}$ & $0.60^{* *}$ & $-0.42^{* *}$ & -0.18 & 0.08 & $-0.90^{* *}$ & -0.11 & $-0.85^{* *}$ & $0.30^{*}$ & $0.99^{* *}$ & $0.38^{* *}$ \\
\hline
\end{tabular}

CCI chlorophyll content index of shoots; TPB total plant biomass (g, DW); WUE water use efficiency (g L $\left.{ }^{-1}, \mathrm{DW}\right) ; N E R$ nitrogen efficiency ratio $(\mathrm{kg}$ kg-1 DW); $E$ nitrogen efficiency utilization (kg, DW); NHI nitrogen harvest index (\%, DW); R:S root-to-shoot ratio; $S I$ whole-plant stress index; $M$-root total mineral content of

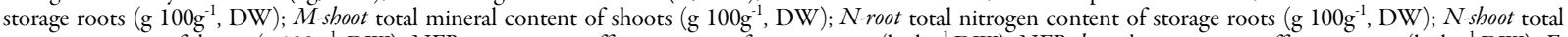
nitrogen content of shoots $\left(\mathrm{g} 100 \mathrm{~g}^{-1}, \mathrm{DW}\right) ; N E R$-root nitrogen efficiency ratio of storage roots $\left(\mathrm{kg} \mathrm{kg}^{-1} \mathrm{DW}\right) ; N E R$-shoot shoot nitrogen efficiency ratio $\left(\mathrm{kg} \mathrm{kg}^{-1} \mathrm{DW}\right) ; E$ root nitrogen efficiency utilization of storage roots $(\mathrm{kg}, \mathrm{DW}) ;$-shoot shoot nitrogen efficiency utilization $(\mathrm{kg}, \mathrm{DW})$.

${ }^{* *}$ Correlation is significant at the 0.01 level $(2$-tailed $) ;{ }^{*}$ Correlation is significant at the 0.05 level $(2$-tailed $)$.

leading to a relative stomatal closure to avoid water loss during drought.

The decrease of CCI was more associated with water scarcity than with the PAR decrease $(-24.6 \%)$ observed inside the shelter. Under fully irrigated conditions, the blind samples had higher chlorophyll content inside the shelter, relatively to open field conditions (data not shown). The CCI decrease inside the shelter was mainly due to water limitation, which could have led to a lower excitation of photosystem II (PSII) through photons of light, through a lower number of ionized chlorophyll molecules (SalehiLisar and Bakhshayeshan-Agdam, 2016). The increase of photorespiration rates is another consequence of photosynthesis inhibition that could be related to the CCI decrease, during drought. The decrease of leaf $\mathrm{CO}_{2} / \mathrm{O}_{2}$ ratio, due to stomata closure led to inhibition of carboxylase and activation of oxygenase functions of the Rubisco (ribulose-1,5-bisphosphate carboxylase/oxygenase) (Igamberdiev et al., 2001; Igamberdiev et al., 2004). The photorespiration is an essential process for the plant growth and survival, when photosynthesis was down-regulated, protecting the chloroplasts and photosystems from photoinhibition and oxidative activity of ROS (Igamberdiev et al., 2001; Igamberdiev et al., 2004; Prasad et al., 2008). The acc. 1036 and 3126 were the exceptions, managing to maintain partially open stomata, allowing photosynthesis activity and nutrient allocation during drought. This is in accordance with Lebot (2009), by referring that the sweet potato root growth, maintenance, and dry matter production is mainly from the carbon fixed in photosynthesis.

WUE is another important trait to determine if a plant has drought resistance, with the most tolerant ones normally showing higher WUE (Ganança $e t$ al., 2018; Gouveia et al., 2019). The WUE is usually related to stomata aperture and is estimated as the ratio of biomass from $\mathrm{CO}_{2}$ assimilation in the photosynthesis, relatively to the water loss by transpiration (Igamberdiev et al., 2004). In sweet potato, drought increased in average $68 \%$ the WUE for most accessions, with acc. 3124 and 3125 showing significantly the highest WUE. The WUE increase can be due to the partial reduction of the stomatal aperture, where acc. were able to maintain leaf turgidity, by minimizing the water loss through transpiration and improving water use for vital activities (Gouveia et al., 2019). This partial reduction of the stomatal aperture still kept good photosynthetic rates under drought. Therefore, as the WUE increase derives from the reduction of water loss by transpiration, it would constitute a drought avoidance response. According to Prabawardani and Suparno (2015), the reduction of WUE in the acc. 3126 and 2938 and the overall sweet potato dry matter, can be related to nitrogen deficiency and transpiration increase. Duman (2012) reported that drought could lead to an overall plant nutrient deficiency, which is strongly related to the soil water availability and plant nitrogen absorption.

\section{The role of plant nutrients during drought}

The mineral nutrients that are found in the soil are classified as macro and micronutrients. Nitrogen, phosphorous and potassium are the primary macronutrient for plant growth and survival. According to Duman (2012), drought conditions can decrease the $\mathrm{N}$ availability from the soil matrix, limiting its uptake and transport from the roots to the shoots. $\mathrm{N}$ represents approximately $80 \%$ of the plant's total absorbed nutrients. It is an essential constituent of amino acids, chlorophyll, other metabolites and cellular structures (Duman 2012; Kaur et al., 2017). Usually, the major part of plant $\mathrm{N}$ is taken in the nitrate $\left(\mathrm{NO}_{3}{ }^{-}\right)$form and less in the ammonium $\left(\mathrm{NH}_{4}^{+}\right)$form (Wang et al., 2009; Sahoo et al., 2010; Kaur et al., 2017).

Besides water availability, nutrient availability also depends on soil $\mathrm{pH}$. The $\mathrm{pH}$ close to neutral (6.5 to 7.5) is ideal to enhance plant growth (Jensen, 2010). The $\mathrm{pH}$ values from the soil of both experimental sites are in this favorable range. Overall, the soil water availability and $\mathrm{pH}$ can be related to the good nutrient uptake and allocation from the underground storage roots to the aboveground 
1044

shoots. The nutrient uptake from soil and allocation in plant organs can be mainly used for leaf and storage roots growth (Duman, 2012). We observed that the sweet potato shoots showed always-higher mineral content relatively to storage roots. Although, drought increased M-root content and led to an M-shoot decrease. It could be related to a greater limitation in the transport of nutrients from the underground to aboveground tissues, since the lack of water reduces the diffusion of minerals to the shoots, according to Duman (2012). Although, beyond the M-shoot decrease, the accessions showed a greater $\mathrm{N}$ content in shoots when compared to storage roots, in both experimental conditions. The registered $\mathrm{N}$-shoot accumulation could be related to the plant use of $\mathrm{N}$ to increase the rate of photosynthesis, while the N-root can be used for the synthesis of proteins for the regulation of cell defense and detoxification (van den Boogaard et al., 1995; Salehi-Lisar and BakhshayeshanAgdam, 2016). The sweet potato registered a decrease of $\mathrm{N}$ shoot under water scarcity that led to a significant NER and $\mathrm{E}$ increase, implying that the $\mathrm{N}$ content in the shoots was applied more efficiently into biomass production, rather than into photosynthesis increase rate. According to Siddiqi and Glass (1981), the NER increase observed in sweet potato can be due to the low accumulation of the nutrient in the whole-plant, in detriment of biomass production. Although not as productive as in control, sweet potato showed to be more efficient in their $\mathrm{N}$-shoot use under drought stress, which is in accordance with Mathur and Goel (2017). The decrease of sweet potato N-root also decreased NER and increased $\mathrm{E}$, which can indicate that although showing a lower $\mathrm{N}$-root accumulation, the acc. displayed a more efficient use of $\mathrm{N}$ for biomass production during drought. The $\mathrm{N}$-root was negatively correlated with E, NER-root, and E-root, under drought. N-root showed a positive correlation between $\mathrm{M}$-root and NHI, confirming a good nutrient relation between the whole-plant and the storage roots. Kaur et al. (2017) also registered a positive correlation between NHI and N content among wheat accessions.

\section{Conclusions}

This study presented meaningful information about the physiological responses of sweet potato accessions when subjected to water scarcity conditions. The sweet potato accessions that allocate nutrients and had improved WUE are the most drought-tolerant which agrees with Farooq et al. (2009). Accessions 3124 and 3125 were the ones that showed the best physiological response to drought stress, namely: higher R:S ratio, lower TPB loss, and lower SI as drought avoidance strategies. Both accessions also showed a good phenotypic flexibility response, with a better WUE and NER for growth and vital functions, and higher Mroot, CCI and N-shoot. This information can be helpful for the overall screening of the sweet potato sensitivity or tolerance to drought, and to the adaptation of this crop to climatic change through breeding programs.

\section{Acknowledgements}

This work was supported by the Programa Operacional Madeira 14-20, Portugal 2020 and the European Union through the European Regional Development Fund [grant number M1420-01-0145-FEDER-000011, CASBio]; and Agência Regional para o Desenvolvimento da Investigação Tecnologia e Inovação, Portugal 2020 and the European Union through the European Social Fund [grant number M1420-09-5369-FSE-000001, ARDITI].

The authors thank the Agricultural Quality Laboratory at the Directory of Laboratory Services and Agrofood Investigation (Camacha, Madeira, Portugal) for their collaboration in the soil analysis.

\section{Conflict of Interest}

The authors declare that there are no conflicts of interest related to this article.

\section{References}

AOAC (2005). Official methods of analysis of the Association of Analytical Chemists International (18th ed), Gaithersburg MD: AOAC International.

Atwell B, Kriedemann P, Turnbull C (1999). Growth analysis: a quantitative approach. In: Plants in action. Australian Society of Plant Scientist. New Zealand Society of plant Biologists and New Zealand Institute of Agricultural and Horticultural Science, Australia pp 203204.

Duman $F$ (2012). Uptake of mineral elements during abiotic stress. In: Ahmad P, Prasad MNV (Eds). Abiotic stress responses in plants: metabolism, productivity and sustainability. Springer New York, pp 270-271.

Ekanayake IJ, Collins W (2004). Effect of irrigation on sweet potato root carbohydrates and nitrogenous compounds. Food Agriculture and Environment 2(1):243-48.

Farooq M, Wahid A, Kobayashi N, Fujita D, Basra SMA (2009). Plant drought stress: effects, mechanisms and management. Agronomy for Sustainable Development 29:185-212.

Ganança JFT, Freitas JGR, Nóbrega HGM, Rodrigues V, Antunes G, Gouveia CSS, ... Lebot V (2018). Screening for drought tolerance in thirty three taro cultivars. Notulae Botanicae Horti Agrobotanici ClujNapoca 46(1):65-74.

Ganança JFT, Freitas JGR, Nóbrega HGM, Rodrigues V, Antunes G, Rodrigues M, ... Lebot V (2015). Screening of elite and local taro (Colocasia esculenta) cultivars for drought tolerance. Procedia Environmental Sciences 29:41-42.

Good AG, Shrawat AK, Muench DG (2004). Can less yield more? Is reducing nutrient input into the environment compatible with maintaining crop production? Trends in Plant Science 9(12):597-605.

Gouveia CSS, Ganança JFT, Slaski J, Lebot V, Pinheiro de Carvalho MÂA (2019). Stable isotope natural abundances $(\delta 13 \mathrm{C}$ and $\delta 15 \mathrm{~N})$ and carbon-water relations as drought stress mechanism response of taro (Colocasia esculenta L. Schott). Journal of Plant Physiology 232:100-106.

Gouveia CSS, Ganança JFT, Lebot V, Pinheiro de Carvalho MÂA (2018). Quantitation of oxalates in corms and shoots of Colocasia esculenta (L.) Schott under drought conditions. Acta Physiologiae Plantarum 40(124):1-11. 
Harris R(1992). Root-shoot ratios. Journal of Arboriculture 18(1):39-42.

Hartemink AE, Johnston M, O'Sullivan JN, PolomaS (2000). Nitrogen use efficiency of taro and sweet potato in the humid lowlands of Papua New Guinea. Agriculture, Ecosystems and Environment 79(2-3):271-280.

Hubick KT, Gibson A (1993). Diversity in the relationship between carbon isotope discrimination and transpiration efficiency when water is limited. In: EhleringerJR, Hall AE, Farquhar GD (Eds). Stable isotopes and plant carbon-water relations. Academic Press Inc. San Diego California, pp 322.

Igamberdiev AU, Bykova NV, Lea PJ, Gardestro P (2001). The role of photorespiration in redox and energy balance of photosynthetic plant cells: a study with a barley mutant deficient in gycine decarboxylase. Physiologia Plantarum 111(4):427-438.

Igamberdiev AU, Mikkelsen TN, Ambus P, Bauwe H, Lea PJ, Gardestrom P (2004). Photorespiration contributes to stomatal regulation and carbon isotope fractionation: A study with barley, potato and Arabidopsis plants deficient in glycine decarboxylase. Photosynthesis Research 81(2):139-152.

IUSS Working Group WRB (2015). World Reference Base for Soil Resources 2014, update 2015 International soil classification system for naming soils and creating legends for soil maps. World Soil Resources ReportsNo. 106FAORome.

Jensen TL (2010). Soil pH and the availability of plant nutrients. IPNI Plant Nutrition Today No. 2. Retrieved 2018 December 15 from http://www.ipni.net/pnt.

John KS, Beegum SUS, Sheela MN, Suja G (2016). Nutrient efficient genotypes in cassava: scope to substitute for chemical fertilizers and in $\mathrm{C}$ sequestration. Acta Horticulturae 1118:193-200.

Kaur B, Kaur G, Asthir B (2017). Biochemical aspects of nitrogen use efficiency: an overview. Journal of Plant Nutrition 40(4):506-523.

Kołodziejczyk M (2014). Effectiveness of nitrogen fertilization and application of microbial preparations in potato cultivation. Turkish Journal of Agriculture and Forestry 38(3):299-310.

Lauteri M, Brugnoli E, Spaccino L (1993). Carbon isotope discrimination in leaf soluble sugars and in whole-plant dry matter in Helianthus annum L. grown under different water conditions. In: Ehleringer JR, Hall AE, Farquhar GD (Eds). Stable Isotopes and Plant Carbon-Water Relations. Academic Press Inc. San Diego California, pp 96.

Lammerts van Bueren ET, Struik PC (2017). Diverse concepts of breeding for nitrogen use efficiency - A review. Agronomy for Sustainable Development 37(50):1-24.

Lebot V (2009). Tropical root and tuber crops: cassava, sweet potato, yams and aroids. In: Atherton J, Rees A (Eds). Crop Production Science in Horticulture. CAB International Cambridge.

Leshem YY, Kuiper PJC (1996). Is there a GAS (general adaptation syndrome) response to various types of environmental stress? Biologia Plantarum 38(1):1-18

Mabhaudhi T, Modi AT (2015). Drought tolerance of selected South African taro (Colocasia esculenta L. Schott) landraces. Experimental Agriculture 51(3):451-66.

Mathur M, Goel A. (2017). Essential plant nutrients. In: Naeem M, Ansari AA, Gill SS (Eds). Essential plant nutrients: uptake, use efficiency, and management. Springer International Publishing Switzerland.
Motsa NM, Modi AT, Mabhaudhi T (2015a). Sweet potato (Ipomoea batatas L.) as a drought tolerant and food security crop. South African Journal of Science 111(11-12):1-8.

Motsa NM, Modi AT, Mabhaudhi T (2015b). Sweet potato response to low-input agriculture and varying environments of KwaZulu-Natal, South Africa: implications for food security strategies. Acta Agriculturae ScandinavicaSection B: Soil and Plant Science 65(4):329-40.

Osakabe Y, Osakabe K, Shinozaki K (2014). Plant environmental stress responses for survival and biomass enhancement. In: Tuteja N, Gill SS (Eds). Climate change and plant abiotic stress tolerance. WileyBlackwell Weinheim Germany, pp 82-83.

Pereira LM, Pereira EM, Revolti LTM, Zingaretti SM, Moro GV (2015). Seed quality, chlorophyll content index and leaf nitrogen levels in maize inoculated with Azospirillum brasilense. Revista Ciencia Agronomica 46(3):630-637.

Prabawardani S, Suparno A (2015). Water use efficiency and yield of sweet potato as affected by nitrogen and potassium application. Journal of Agricultural Science 7(7):128-137.

Prasad PVV, Staggenborg SA, Ristic Z (2008). Impacts of drought and/or heat stress on physiological, developmental, growth, and yield processes of crop plants. In: Ahuja LR, Reddy VR, Saseendran SA, Qiang Y (Eds). Response of crops to limited water: understanding and modeling water stress effects on plant growth processes. American Society of Agronomy, Crop Science Society of America, Soil Science Society of America (1st ed) USA pp 304308.

Robinson D, Handley LL, Scrimgeour CM, Gordon DC, Forster BP, Ellis $\mathrm{RP}(2000)$. Using stable isotope natural abundances ( $\delta^{15} \mathrm{~N}$ and $\left.\delta^{13} \mathrm{C}\right)$ to integrate the stress responses of wild barley (Hordeum spontaneum C. Koch.) genotypes. Journal of Experimental Botany 51(342):41-50.

Rundel PW, Sharifi MR (1993). Carbon isotope discrimination and resource availability in the desert shrub Larrea tridentata. In: Ehleringer JR, Hall AE, Farquhar GD (Eds). Stable isotopes and plant carbonwater relations. Academic Press Inc. San Diego California, pp 177.

Sahoo MR, Dasgupta M, Kole PC, Mukherjee A (2010). Biochemical changes in leaf tissues of taro [Colocasia esculenta L. (Schott)] infected with Phytophthora colocasiae. Journal of Phytopathology 158(3):154 159.

Salehi-Lisar SY, Bakhshayeshan-Agdam H (2016). Drought stress in plants: causes, consequences, and tolerance. In: Hossain MA, Wani SH, Bhattacharjee S, Burritt DJ, Tran L-SP (Eds). Drought stress tolerance in plants: physiology and biochemistry. Springer Switzerland, pp 1-8.

Shao G, Yuan M, Liu N, Ji J, Yu W (2015). Effect of rain shelters and drought on leaf water status and photosynthetic parameters in tomato. Archives of Agronomy and Soil Science 61(9):1273-1288.

Sharma HK, Kaushal P (2016). Introduction to tropical roots and tubers. In: Sharma HK, Njintang NY, Singhal RS, Kaushal P (Eds). Tropical roots and tubers - production, processing and technology.John Wiley \& Sons Ltd Oxford, pp 1-22.

Siddiqi MY, Glass ADM (1981). Utilization index: a modified approach to the estimation and comparison of nutrient utilization efficiency in plants. Journal of Plant Nutrition 4(3):289-302.

Smittle DA, Hall MR, Stansell JR (1990). Effects of irrigation regimes on yield and water use by sweet potato. Journal of the American Society for 
1046

Horticultural Science 115(5):712-714.

Steenbjerg F, Jakobsen ST (1963). Plant nutrition and yield curves. Soil Science 95(1):69-88.

Tiwari R, Mamrutha HM (2013). Precision phenotyping for mapping of traits for abiotic stress tolerance in crops. In: Salar RK, Gahlawat SK, Siwach P, Duhan JS (Ed). Biotechnology: prospects and applications. Springer Sirsa, pp 84 .

Undersander D, Mertens DR, Thiex N (Eds) (1993). Two step total dry matter determination of wet samples. In: Forage Analysis Procedures. National Forage TestingAssociation Omaha, pp 2426.
Van den Boogaard R, Kostadinova S, Veneklaas E, Lambers H (1995). Association of water use efficiency and nitrogen use efficiency with photosynthetic characteristics of two wheat cultivars. Journal of Experimental Botany 46:1429-1438.

Wang J, Zhou Y, Dong C, Shen Q, Putheti R (2009). Effects of $\mathrm{NH}_{4}^{+}$$\mathrm{N} / \mathrm{NO}_{3}-\mathrm{N}$ ratios on growth, nitrate uptake and organic acid levels of spinach (Spinacia oleracea L.). African Journal of Biotechnology $8(15): 3597-3602$.

Yuan S, Peng S (2017). Exploring the trends in nitrogen input and nitrogen use efficiency for agricultural sustainability. Sustainability $9(10): 1-15$. 